\title{
Consumer Behavior Towards Purchase Intention of Seafood Processed Products in The Province of West Nusa Tenggara
}

\author{
${ }^{1}$ Zulkieflimansyah, ${ }^{2}$ Muhammad Nurjihadi, ${ }^{3}$ Jayanti Mandasari, ${ }^{4}$ Ayu Levia Tryana, \\ ${ }^{5}$ Rozzy Aprirachman \\ 1,2,3,4,5 Sumbawa University of Technology, West Nusa Tenggara, Indonesia
}

\begin{abstract}
This study aims to analyze the variables that influence purchasing decisions for processed marine products in the Province of West Nusa Tenggara. Determination of the number of respondents who will be the sample using the 10\% Margin of Error (MOE) method with a total of 100 respondents consisting of several districts in West Nusa Tenggara Province. The analytical tool used in this research is Multiple Linear Regression to see the relationship between the independent variable and the dependent variable. The research was conducted using a Likert scale on each research variable with ordinal data and transformed into intervals using the Method Successive Interval (MSI), using the MS.excel application, while the Multiple Linear Regression data processing used the Stata application. The result of this research is that the consumer behavior of processed seafood in West Nusa Tenggara Province is slightly different from the conventional theory of consumer behavior, where the brand has a negative effect on purchasing decisions of 0.2129039 points, and convenience has a negative effect on purchasing decisions of 0.1199636 points. Meanwhile, price, packaging, promotion, benefits, and consumer traditions have a positive effect on purchase intention. Processed seafood products in West Nusa Tenggara Province have different consumer characteristics from other products in general.
\end{abstract}

\section{Keyword: Consumer Behaviour, Seafood Processed Product, Multiple Regression}

\section{Introduction}

The formation of purchases is the main goal of marketing, purchases can occur from a series of consumer behavior processes, process of forming consumer behavior is something that is currently being studied by many marketers is because consumers have various views, perceptions, and different references to a product and consumer behavior. This is what will affect the purchase decision (Purboyo and Huda, 2017).

Consumer behavior will appear if a person's behavior has a need or desire to get something. Humans are often faced with various choices to meet their needs. An understanding of behavior is very important for projecting consumer demand for products and is used as an important capital for companies/industry to achieve their business development goals.

The study of consumer behavior is oriented towards individual or group patterns that shape behavior to make decisions that aim to fulfill a set of needs and desires by empowering or utilizing available resources such as money, energy, and time. An understanding of good consumer behavior will be a guarantee for the survival of the company and as a medium to sharpen its marketing strategy that pays attention to the basic aspects that change in consumer behavior patterns. Therefore, consumer behavior in purchasing decisions for processed marine products in the province of West Nusa Tenggara (NTB) is very interesting to study. NTB Province is an archipelagic province which has a marine area of $29,159.04 \mathrm{~km}^{2}(58.13 \%)$ wider than its land area of $20,153.15 \mathrm{~km}^{2}$ consisting of two large islands (Lombok Island and Sumbawa Island) and 332 small islands. 
Tabel 1. Sea Water Area in West Nusa Tenggara Province

\begin{tabular}{|l|l|l|}
\hline No & Name of Area & Area $\left(\mathbf{K m}^{2}\right)$ \\
\hline 1 & Java Sea & $3.059,0$ \\
\hline 2 & Flores Sea & $8.847,0$ \\
\hline 3 & Indian Ocean & $9.813,0$ \\
\hline 4 & Lombok Strait & $1.355,0$ \\
\hline 5 & Alas Gulf & $1.035,0$ \\
\hline 6 & Sape Strait & $2.893,0$ \\
\hline 7 & Selat Strait & $1.459,0$ \\
\hline 8 & Cempi Gulf & 239,0 \\
\hline 9 & Bima Gulf & 184,0 \\
\hline 10 & Waworada Gulf & 275,0 \\
\hline Total & & $\mathbf{2 9 . 1 5 9 , 0}$ \\
\hline
\end{tabular}

Source: Department of Marine Affairs and Fisheries West Nusa Tenggara Province

The fishery potential of West Nusa Tenggara Province (NTB) is very high when viewed from the size of the sea area, so efforts are needed to increase the value of marine processed products and increase the community's economy. The data from the Department of Maritime Affairs and Fisheries of the Province of NTB related to the achievement of processed marine products in 2017 shows a total of 199,895 tons of products, and in 2018 there was an increase of 210,738 tons, this shows that the development of processed seafood production is increasing. Various processed marine products in NTB have various types, ranging from processed fish and seaweed products, such as shredded fish, smoked fish, salted fish, lunkhead, jelly, crackers, sweets, and other preparations.

NTB Province Long Term Development Plan Phase IV development of marine and fisheries is directed at supporting the establishment of a solid economic structure based on competitive advantages in various regions supported by qualified and competitive human resources. The level of education services and the increasingly advanced marine and fishery science and technology capabilities and the increasing welfare of the marine and fishery community and contribute to reducing the unemployment rate and the poor, especially in coastal areas. Regional Regulation Number 12 of 2017 concerning Zoning Plans for Coastal Areas and Small Islands for the Province of NTB Year 2017 - 2037 that the utilization of the sea space of the Province of NTB has been allocated for various activities that support the development of the marine and fisheries sector in general use zones, conservation zones, sea lanes, migration biota, and certain national strategic zones.

In addition, the processed industrial sector continues to make a positive contribution to NTB's economic growth as reflected in the growth of the Gross Regional Domestic Product (GDP) in the third quarter of 2020. Based on data from the Central Statistics Agency (BPS) in 2020, the contribution of the industrial sector in NTB in the second quarter was 3.72 percent, then in the third quarter, the contribution of the industrial sector to GRDP increased to 5.05 percent. So it is hoped that marine processed products can continue to have a positive impact on the economy, especially for business actors and the NTB provincial government, by understanding the behavior that can influence consumers in making a decision to buy a product so that producers/business actors get reciprocal information from consumers to use for improvement evaluation. Based on the explanation above, this study aims: "to determine the influence of consumer behavior on purchasing decisions of processed marine products in the Province of West Nusa Tenggara (NTB)".

\section{Body Text}

Kotler and Keller (2012) define consumer behavior as: "is the study of how individuals, groups, and organizations select, buy, use, and dispose of goods, services, ideas, or experiences to satisfy their needs and wants. ". This means that according to them, consumer behavior is the study of how individuals, groups, and organizations choose, buy, use, and utilize goods, services, ideas, or experiences to satisfy their needs and desires.

Consumer behavior is influenced by marketing stimuli (products, services, prices, distribution, communication) and other stimuli (economics, technology, politics, culture) which will then affect consumer 
psychology (motivation, perception, learning, memory) and consumer characteristics (culture)., social, personal) then consumers will go through the stages of the buying decision process which involves problem recognition, information seeking, alternative assessment of purchasing decisions, and post-purchase behavior and finally, consumers make purchasing decisions (Purboyo et. all. 2021)

A marketing strategy is a plan designed to influence exchanges in achieving organizational goals. Usually, marketing strategies are directed at increasing the likelihood or frequency of consumer behavior, such as increasing visits to certain stores or purchasing certain products. This can be achieved by developing and presenting a marketing mix that is directed at the basis of the chosen target (Setiadi, 2019). In his writings, Indriani (2018) explains that there are 5 (five) stages in the consumer purchasing decision process, starting with problem recognition where consumers are identifying needs by comparing current and expected conditions; information search where consumers seek information from internal and external sources regarding the desired product brand; evaluation of existing options (evaluations of alternatives) to obtain the best product; purchase of products (product purchases) that have been decided to be purchased; and postpurchase evaluation, a stage where consumers have real experience with the products they have purchased.

The type of research in this research is explanatory research. The object of research in this study is consumers who purchase processed marine products in the Province of West Nusa Tenggara (NTB). The type of data used is primary data. Sampling in this study used purposive sampling and used the margin of error (moe) formula so that 100 respondents were obtained consisting of several regions in the province of West Nusa Tenggara, namely Sumbawa Regency, West Sumbawa Regency, Bima Regency, Dompu Regency, West Lombok, Central Lombok, and East Lombok. Collecting data in this study using questionnaires distributed via a google form. The answers to each question were measured using a Likert scale with an answer range of 1 to 5 consisting of (5) strongly agree, (4) agree, (3) undecided (2) disagree, (1) strongly disagree. The data analysis technique in this study used analytical tools in the form of MSI (Method Of Succesive Interval) and multiple linear regression analysis. Here's how to determine the number of respondents in the study

$$
\mathrm{n}=\frac{Z^{2}}{4(M O E)^{2}}
$$

$$
\begin{array}{ll}
\mathrm{n} & =\text { Number of sampel } \\
\mathrm{Z} & =\text { Normal distribution in significant level } 5 \%=1.96 \\
\mathrm{MOE} & =\text { Margin of Error with } 10 \% \text { or } 0.1
\end{array}
$$

With a confidence level of $95 \%$ or $\mathrm{Z}=1.96$ and a margin of error of $10 \%$, it can be calculated the number of respondents between $96.04 \sim 100$ respondents as the research sample.

The analytical method used in this research is descriptive quantitative. The quantitative method is done by analyzing the data through a computer program with an analytical tool in the form of MSI (Method Of Successive Interval). Using ordinal data can result in the model being studied being inappropriate or wrong. Because the data studied in this study are not interval data but ordinal data, it is necessary to transform the data from the ordinal scale to interval scale data using MSI (Method Of Successive Interval). After the data is transformed from ordinal to interval, data management is carried out using multiple linear regression with the static application.

$\mathrm{Y}=\mathrm{a}+\beta 1 . \mathrm{X} 1+\beta 2 . \mathrm{X} 2+\beta 3 . \mathrm{X} 3+\beta 4 . \mathrm{X} 4+\beta 5 . \mathrm{X} 5+\beta 6 . \mathrm{X} 6+\beta 7 . \mathrm{X} 7+\mathrm{Ui}$

$\mathrm{Y}=$ Purchase intention (dependent variable)

$\mathrm{a}=$ coefficient

$\mathrm{X} 1=$ Price

$\mathrm{X} 2=$ Brand

$\mathrm{X} 3$ = Packaging

$\mathrm{X} 4=$ Convenience

$\mathrm{X} 5=$ Promotion

X6 $=$ Benefits

$X 7=$ Consumer Tradition

$\beta 1, \beta 2, \beta 3, \beta 4, \beta 5, \beta 6, \beta 7=$ Parameter of Independent Variables 
The steps taken before processing the data are testing the validity and reliability. Validity test was conducted to measure whether or not the items in the questionnaire used were valid. The criteria are valid or not by looking at the $r$ count $<r$ table with a significance of 0.05 . In addition to testing the validity, reliability testing is also carried out, namely to measure the consistency of the measuring instrument used if retested. The criteria are said to be reliable if the Conbach Alpha coefficient on all variables is $>0.6$. \% (Ghozali, 2016). After that, the analysis carried out is statistical description analysis, classical assumption test and multiple linear regression test.

\section{Result and Discussion}

In regression, the estimation parameters need to meet criteria that are often abbreviated as BLUE, namely Best (estimated parameters minimize variance (squared) error), Linear (estimated equations are linear), Unbiased (unbiased estimation parameters), and Estimator (parameters are good estimators). for population parameters). An unbiased and consistent estimator means that the parameter corresponds to the population parameter and gets closer to the population parameter when the sample is added (plim $\hat{\beta}=\beta$ ). In processing multiple linear regression data, it is necessary to test the classical assumptions to get a better model, namely, the multicollinearity test and the heteroscedasticity test.

Tabel 2. Multikollinearitas test using VIF Value

\begin{tabular}{|l|l|l|}
\hline Variable & VIF & $1 / \mathrm{VIF}$ \\
\hline packaging & 3.86 & 0.258815 \\
\hline Brand & 3.69 & 0.271064 \\
\hline convenience & 3.07 & 0.325647 \\
\hline promotion & 2.91 & 0.343321 \\
\hline benefits & 2.85 & 0.350419 \\
\hline Price & 2.18 & 0.457892 \\
\hline consumer n & 2.07 & 0.48371 \\
\hline & & \\
\hline Mean VIF & 2.95 & \\
\hline
\end{tabular}

Multicollinearity refers to the existence of a linear relationship between the independent variables in the multiple linear regression model, the regression model is considered qualified if there is no multicollinearity in the model. If the VIF value is greater than 10 or the tolerance $(1 / \mathrm{VIF})$ is .01 or less, it indicates the presence of multicollinearity. So based on the above results, our data does not have a strong multicollinearity variable. From the table above, each independent variable has a VIF value below, where the highest VIF value is 3.86, namely the packaging variable, while the lowest VIF value is the consumer tradition variable 2.95. Overall the mean value of VIF $=2.97$ and shows that the model built is free from multicollinearity.

Tabel 3. Breusch-Pagan / Cook-Weisberg test for heteroskedasticity

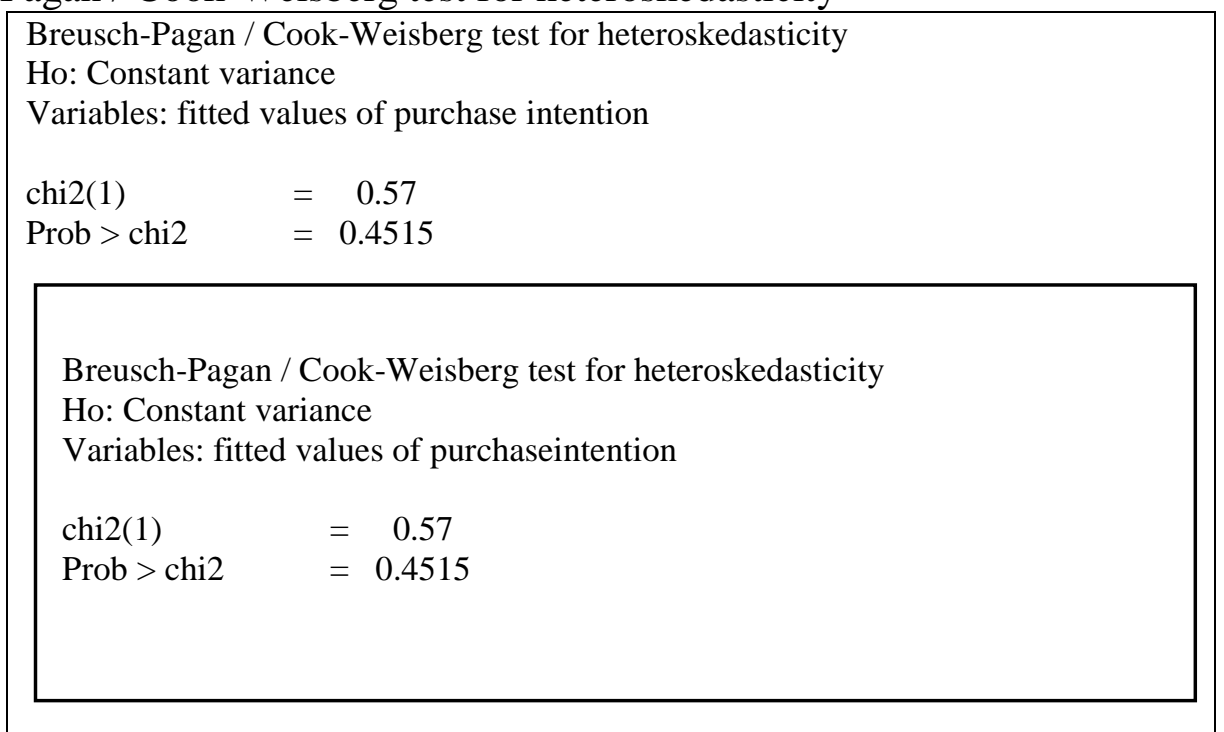


Heteroscedasticity is a condition when the error variance changes as the value of the independent variable $\mathrm{x}$ changes. Heteroscedasticity generally does not cause indicators to be biased but causes errors in the calculation of the standard error, which reduces the efficiency of the model (Bennedict J. et all 2010). Based on the results of the Breusch-Pagan / Cook-Weisberg test, where the value of Prob $>$ chi $2=0.4515$, greater than alpha (0.05), it can be concluded that the multiple linear regression estimation model is free from heteroscedasticity problems.

Tabel 4. Multiple linear regression

\begin{tabular}{|c|c|c|c|c|c|c|}
\hline Source & SS & df & MS & \multicolumn{3}{|c|}{ Number of obs $=100$} \\
\hline Model & 38.5256161 & 7 & 5.50365944 & \multicolumn{3}{|c|}{$F(7,92)=22.68$} \\
\hline Residual & 22.3288687 & 92 & 0.242705095 & \multicolumn{3}{|c|}{ Prob $>$ F $=0.000$} \\
\hline Total & 60.8544848 & 99 & 0.614691766 & \multicolumn{3}{|c|}{ R-squared $=0.6331$} \\
\hline & & & & \multicolumn{3}{|c|}{ Adj R-squared = 0.6052} \\
\hline & & & & \multicolumn{3}{|c|}{ Root MSE $=0.49265$} \\
\hline Purchase intention & Coef. & Std. Err. & $\mathbf{t}$ & $\mathbf{P}>\mathbf{t}$ & \multicolumn{2}{|c|}{ [95\% Conf. Interval] } \\
\hline Price & 0.2278283 & 0.0945322 & 2.41 & 0.018 & 0.0400791 & 0.4155774 \\
\hline Brand & -0.2129039 & 0.13459 & -1.58 & 0.117 & -0.4802112 & 0.0544035 \\
\hline packaging & 0.0507686 & 0.1297835 & 0.39 & 0.697 & -0.2069926 & 0.3085297 \\
\hline convenience & -0.1199636 & 0.1099637 & -1.09 & 0.278 & -0.338361 & 0.0984339 \\
\hline promotion & 0.0710598 & 0.1029261 & 0.69 & 0.492 & -0.1333603 & 0.27548 \\
\hline Benefit & 0.2099146 & 0.1064335 & 1.97 & 0.052 & -0.0014716 & 0.4213007 \\
\hline Consumer tradition & 0.6495814 & 0.0980098 & 6.63 & 0 & 0.4549254 & 0.8442374 \\
\hline _cons & 0.3841711 & 0.3033407 & 1.27 & 0.209 & -0.2182897 & 0.986632 \\
\hline
\end{tabular}

Purchaseintention $=0.3841711+0.2278283$. Price -0.2129039 . brand +0.0507686 . packaging 0.1199636 . convenience +0.0710598 . promotion +0.2099146 . benefit +0.6495814 . consumertradition + $\mathrm{Ui}$

In the case of consumer buying interest in marine processed products in West Nusa Tenggara Province, there are several variables that have a positive effect on consumer buying interest in marine processed products, namely price, packaging, promotion, benefit, and consumer tradition. Meanwhile, from the results of this study, it was found that consumer behavior in the provision of West Nusa Tenggara is not too concerned with the brand and convenience of processed seafood products. By looking at the R-square value $=0.6331$ for the multiple linear regression models above, it indicates that all of the independent variables above which consist of price, brand, packaging, convenience, promotion, benefit, consumer tradition can explain the dependent variable purchase intention of $63.31 \%$, while 36.69 percent is explained by other variables outside the model.

To see the effect of the independent variable simultaneously on the dependent variable, the $F$ test was carried out, while to see the effect of the independent variable partially on the dependent variable, the t-test was used. The F test is carried out by comparing the alpha and F table values with the hypothesis

$$
\begin{aligned}
& \mathrm{H} 0: \beta 0=\beta 1=\beta 2=\beta 3=\beta 4=\ldots . .=\beta \mathrm{k}=0 \\
& \mathrm{H} 1: \beta 0=/ \beta 1=/ \beta 2=/ \beta 3=/ \beta 4=\ldots . .=\beta \mathrm{k}=/ 0
\end{aligned}
$$

In multiple linear regression, the $\mathrm{F}$ test is performed by looking at the null hypothesis and the alternative hypothesis with the rejection criteria rejecting $\mathrm{H} 0$ if prob $>\mathrm{F}$ is less than the alpha value. From the results of the data processing output, it is obtained that the value of Prob $>\mathrm{F}=0.000$ while the value of alpha $=0.05$, the value of Prob>F is smaller than negligent which means there is not enough evidence to accept $\mathrm{H} 0$, so that $\mathrm{H} 1$ is accepted with the interpretation that simultaneously the entire independent variable is price, brand, packaging, convenience, promotion, benefit, consumer tradition have a significant effect on the 
dependent variable purchase intention in one model. To see the partial relationship in the multiple linear regression model, a t-test by rejecting the null hypothesis will be rejected if the $\mathrm{P}>\mathrm{t}$ value is less than alpha

$$
\begin{aligned}
& \mathrm{H} 0: \beta \mathrm{k}=0 \\
& \mathrm{H} 1: \beta \mathrm{k}=10
\end{aligned}
$$

Table 5. Partial test (t-test)

\begin{tabular}{|l|l|l|l|}
\hline Independent Variable & $\mathrm{P}>\mathrm{t}$ & alpha & Decision \\
\hline price & 0.018 & 0.05 & Accept H1 \\
\hline brand & 0.117 & 0.05 & Accept H0 \\
\hline packaging & 0.697 & 0.05 & Accept H0 \\
\hline convenience & 0.278 & 0.05 & Accept H0 \\
\hline promotion & 0.492 & 0.05 & Accept H0 \\
\hline benefit & 0.052 & 0.0 .5 & Accept H0 \\
\hline Consumer tradition & 0.000 & 0.05 & Accept H1 \\
\hline
\end{tabular}

From the results of the t-test, it is found that there are two variables that have a significant effect on purchase intention, namely price and consumer tradition. Meanwhile, brand, packaging, convenience, promotion, and benefit do not have a significant effect in determining consumer behavior, namely purchase intention in processed seafood products.

Figure 1. Relation Model to Purchase Intention

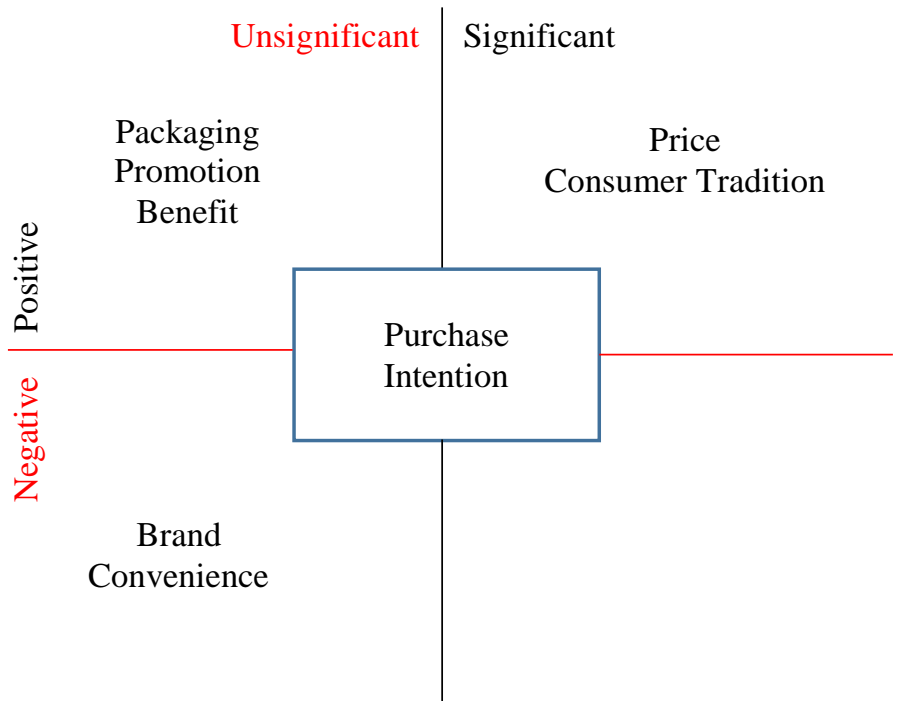

From the results of multiple linear regression management, the simultaneous test and partial test show that there are only two variables that play an important role in determining consumer behavior towards the purchase of marine processed products in West Nusa Tenggara Province, namely price and consumer tradition. The tradition of the people of West Nusa Tenggara who like to consume processed marine products causes consumers not to think too much about the price of these products. The measure of demand says that when the price increases, the quantity demanded of the goodwill decrease. However, in processed seafood products in NTB, when these goods are difficult to obtain and the price is relatively high, people will still buy seafood products because it relates to the consumption tradition of the people of West Nusa Tenggara who make seafood products as the main side dish after rice. The tradition of the community that likes to consume fish and processed marine products is a program and campaign from the West Nusa Tenggara Provincial government, so as to create a consumer tradition that has a positive impact on the development of small and medium scale industries. With the tradition of consumers who like to consume 
processed marine products, it will create a new market share from community-based industries that manage marine products into processed product that has a clear market share.

\section{Conclusion}

Consumer traditions and prices are the main factors in determining consumer behavior in the province of West Nusa Tenggara, which is the result of the West Nusa Tenggara government program campaigning to consume processed seafood products, thus forming a consumer consumption tradition that becomes a new market share for industrial products based on community. Other variables have no significant effect in shaping consumer behavior on the purchase intention of processed seafood products, the variables are packaging, promotion, benefit, brand, and convenience. This is because the people of West Nusa Tenggara province do not really care about the packaging of marine processed products, and promotions are not very effective because it is a government program in campaigning for consuming processed seafood products.

\section{Reference:}

1. Ghozali, I. (2016 ). Aplikasi Analisis Multivariate Dengan Program SPSS. Semarang: Badan Penerbit Universitas Diponegoro.

2. Jusuf, Dewi Indriani. 2018. Perilaku Konsumen Di Masa Bisnis Online. Yogyakarta : Andi

3. S.A Putri \& A.D.B Tamami. 2021. Perilaku Konsumen Dalam Pembelian Frozen Food. Agriscience. Volume 2

4. Purboyo, dkk. 2021. Perilaku Konsumen (Tinjauan Konseptual Dan Praktis). Bandung : CV. Media Sains Indonesia

5. Setiadi, J. Nugroho (2019). Perilaku Konsumen Perspektif Kontemporer pada Motif, Tujuan, dan Keinginan Konsumen. Jakarta : Prenada Media Group

6. Yappy, Benedict, dkk (2010). Pelatihan Komputasi Dengan Stata, Departemen Ilmu Ekonomi Universitas Indonesia

7. Yusnita, M. (2019). Pola Perilaku Konsumen dan Produsen. Semarang: ALPRIN 